\title{
Pengembangan Materi Ajar Pembelajaran Sejarah Maritim menggunakan Sumber Lokal Wadu Tanda Rahi di STKIP Yapis Dompu
}

\author{
Sumiyati ${ }^{1}$, Mulya Yusnarti ${ }^{2}$ \\ ${ }^{1}$ Program studi Pendidikan Sejarah, STKIP Yapis Dompu \\ ${ }^{2}$ Program studi Pendidikan Guru Sekolah Dasar, STKIP Yapis Dompu \\ E-mail: sumimaci068@gmail.com
}

\begin{tabular}{l}
\hline Article Info \\
\hline Article History \\
Received: 2021-09-20 \\
Revised: 2021-09-28 \\
Published: 2021-10-16
\end{tabular}

Keywords:

Development;

Device;

Critical thinking;

Wadu tanda rahi.

\begin{abstract}
Maritime history learning at STKIP Yapis Dompu needs to be developed learning tools with the aim to improve students' critical thinking skills. Maritime history learning that takes place at STKIP Yapis Dompu mostly relies on nationally oriented maritime history print books, such as shipping and trade between islands, the occurrence of cultural interactions nationally and political integration built between regions. In this study using research and development methods (R\&) using a FourD model with four stages of development consisting of Define, Desaign, Develop, and Disseminate. Development is carried out in history students semester 5 numbering 20 people in the odd semester of the academic year 2020/2021. The use of learning devices to students' critical thinking skills can be seen from the effect size value calculated using SPSS and the calculation results show that Cohen's $d$ value of $1,268>0.8$ which means that the effectiveness of the use of learning devices against students' critical thinking skills falls into a large category so that it can be concluded that the use of learning devices can improve participants' critical thinking skills. Learn significantly
\end{abstract}

\begin{tabular}{l}
\hline Artikel Info \\
\hline Sejarah Artikel \\
Diterima: 2021-09-20 \\
Direvisi: 2021-09-28 \\
Dipublikasi: $2021-10-16$
\end{tabular}

Kata kunci:

Pengembangan; Perangkat;

Berpikir Kritis;

Wadu tanda rahi.

\begin{abstract}
Abstrak
Pembelajaran sejarah Maritim di STKIP Yapis Dompu perlu dilakukan pengembangan perangkat pembelajaran dengan tujuan untuk meningkatkan kemampuan berpikir kritis mahasiswa. Pembelajaran sejarah maritim yang berlangsung di STKIP Yapis Dompu Sebagian besar mengandalkan buku cetak sejarah maritim yang berorentasi secara nasional, seperti pelayaran dan perdagangan antar pulau, terjadinya interaksi budaya secara nasional serta integrasi politik yang terbangun antar wilayah. Dalam penelitian ini menggunakan metode penelitian pengembangan (Research and Development/R\&) dengan menggunakan model FourD dengan empat tahap pengembangan yang terdiri dari Define, Desaign, Develop, dan Disseminate. Pengembangan di lakukan pada mahasiswa Sejarah semester 5 sejumlah 20 orang pada semester Ganjil tahun ajaran 2020/2021. Adapun hasil penelitian diperoleh Efektifitas penggunaan Perangkat pembelajaran terhadap keterampilan berpikir kritis mahasiswa dapat dilihat dari nilai effect size yang dihitung menggunakan SPSS dan hasil perhitungan menunjukkan bahwa nilai Cohen's d sebesar $1.268>0.8$ yang artinya bahwa efektifitas penggunaan Perangkat pembelajaran terhadap keterampilan berpikir kritis mahasiswa termasuk ke dalam kategori besar (large) sehingga dapat disimpulkan bahwa penggunaan Perangkat pembelajaran dapat meningkatkan keterampilan berpikir kritis peserta didik dengan signifikan
\end{abstract}

\section{PENDAHULUAN}

Sistem Pembelajaran terus berkembang dengan begitu cepat, perkembangan jaman tentu mempengaruhi seluruh sector kehidupan termasuk sistim pendidikan. Sistim pembelajaran modern sekarang hamper seluruhnya berbasis teknologi informasi, hal ini memberikan jaminan akan meluasnya jangkauan akses dimana saja dan kapan saja. "Revolusi industri 4.0 memudahkan orang untuk terhubung secara online, seperti media sosial dan dapat mengakses informasi dengan cepat. Salah satu langkah pemanfaatan teknologi jaringan dan teknologi informasi bagi pengembangan sistem pembelajaran di perguruan tinggi adalah sistem kuliah daring (dalam jaringan) antar perguruan tinggi"(Mustofa et al., 2019), Pandemic Covid-19 menjadi salah satu pendorong penerapan pembelajaran Daring sesuai dengan tujuan pengembangan pendidikan yang merata. Walaupun kondisi penerapan sistim pendidikan daring terkesan dipaksakan tetap harus dilaksanakan sebaik mungkin. Penerapan pembelajaran daring tentu mengalami kendala 
dan hambatan, sehingga perlu adanya terobosan dan pengembangan yang bias mendukung keberlangsungan pembelajaran daring. STKIP Yapis Dompu merupakan institusi pendidikan tinggi yang selalu mendukung kebijakan pemerintahan, salah satu bentuk dukunganya yaitu penerapan pembelajaran yang berupaya meminimalisir penyebaran COVID 19, sehinga perlu dikembangkan perangkat pembelajaran daring, Beberapa keunggulan dari pembelajaran daring yaitu: pembelajaran daring memiliki fleksibilitas dalam pelaksanaannya dan mampu mendorong munculnya pembelajaran mandiri serta memotivasi mahamahamahasiswa untuk lebih aktif dalam pembelajaran, pembelajaran daring juga mendorong munculnya perilaku social distancing dan meminimalkan munculnya keramaian mahasiswa sehingga dapat mengurangi potensi penyebaran Covid-19 dilingkungan kampus khususnya pada matakuliah sejarah maritim prodi pendidikan sejarah STKIP Yapis Dompu (Sadikin \& Hamidah, 2020).

Pembelajaran sejarah maritime memiliki tujuan dalam memberikan pemahaman secara menyeluruh terhadap realitas sejarah Indonesia yang banyak dipengaruhi oleh laut. Indonesia merupakan Negara kepulauan terbesar di dunia, kenyataan ini tidak sejalan dengan pemahaman kebaharian yang dimiliki oleh masyarakat Indonesia. Laut cenderung dipandang sebagai pemisah bukan penyatu bagi seluruh pulau-pulau yang terintegrasi dalam Negara Kesatuan Republik Indonesia sehingga laut dipandang sebagai tempat yang menakutkan dan berbahaya. Indonesia sebagai Negara kepulauan seharusnya berorentasi kemaritiman hal ini sejalan dengan letak geografis dan fakta sejarah Indonesia yang lebih banyak dipengaruhi oleh laut. Interaksi Masyarakat dengan laut dimasa lalu telah terbangun secara itensif, interaksi tersebut mencakup, pelayaran, perdagangan, terciptanya hokum laut, tradisi bahari, mitologi laut, perompakan. (Relevansi \& Ahmad, 2017)

Pembelajaran sejarah maritim menjadi salah satu mata pelajaran wajib yang bertujuan untuk memberikan pemahaman secara menyeluruh terhadap realitas sejarah Indonesia yang banyak dipengaruhi oleh laut, Sebagaimana dikatakan oleh Lapian, bahwa pendekatan sejarah maritim Indonesia hendaknya melihat seluruh wilayah perairannya sebagai pemersatu yang mengintegrasikan ribuan pulau yang terpisah-pisah. Lapian melihat wilayah-wilayah itu sebagai suatu kesatuan sistem dari berbagai satuan bahari
(Yuliati, 2014). Dalam pandangan umum masyarakat Indonesia laut cenderung dipandang sebagai pemisah dan bukan penyatu, Interaksi masyarakat dengan laut dimasa lalu telah terbangun secara itensif, interaksi tersebut mencakup, pelayaran, perdagangan, terciptanya hokum laut, tradisi bahari,mitologi laut, perompakansatunya Bima dan Dompu merupakan kerajaan maritim, terbukti dengan aktifitas dagang yang ramai di pelabuhan Bima hingga abad ke-19 (Sumiyati, 2018) peninggalan bersejarah seperti pelabuhan Bima dan Sape, Lopi Penge, situs Nanga Sia dan wadu Tanda Rahi, menjadi bukti penting yang perlu dijelaskan pada generasi penerus selanjutnya melalui pembelajaran sejarah.

Pembelajaran sejarah maritim yang berlangsung di STKIP Yapis Dompu Sebagian besar mengandalkan buku cetak sejarah maritim yang berorentasi secara nasional, seperti pelayaran dan perdagangan antar pulau, terjadinya interaksi budaya secara nasional serta integrasi politik yang terbangun antar wilayah. Materi tersebut bersifat nasional dan umum, mahasiswa hanya mampu memahami sejarah maritim sebagai materi yang menjelaskan tentang aktifitas laut dimasa lampau, seputar pelayaran dan perdagangan yang dilakukan oleh suku-suku Bugis, Makassar, Jawa, Sumatera, pelabuhan-pelabuhan besar dan jalur rempah yang berada di daerah lainya, dengan demikian perlu adanya penggunaan sejarah local yang diintegrasikan dalam materi ajar, hal ini bertujuan untuk lebih mendekatkan peserta didik dengan objek sejarah dan memungkinkan peserta didik lebih mudah dalam menggali informasi terkait dengan kajian sejarah. Pembelajaran sejarah maritim menjadi salah satu mata pelajaran dengan tujuan memberikan pemahaman secara menyeluruh terhadap realitas sejarah Indonesia yang banyak dipengaruhi oleh laut.

Dalam pandangan masyarakat Indonesia secara umum laut cenderung dipandang sebagai pemisah dan bukan penyatu, Interaksi masyarakat dengan laut dimasa lalu telah terbangun secara itensif, interaksi tersebut mencakup, pelayaran, perdagangan, terciptanya hukum laut, tradisi bahari, mitologi laut, perompakan (Ahmad,2017) untuk meningatkan kemampuan berpikir kritis mahasiswa . Sebagai upaya dalam meningkatkan keterampilan berpikir kritis mahasiswa, perlu adanya desain perangkat pembelajaran yang interaktif dan menarik menggunakan objek sejarah daerah 
sesuai materi yang disajikan. Dengan demikian, mahasiswa mampu memahami dan menganalisis sejarah maritim disekitar mereka dengan pembelajaran di dalam kelas, Perlu adanya pengembangan perangkat pembelajaran Sejarah Maritim Wadu Tanda Rahi menggunakan model Project Based Learning (PjBL) untuk meningkatkan keterampilan berpikir kritis mahasiswa . Berpikir kritis yaitu bagian dari cognitive skill yang terdiri dari interprestasi, analisis, evaluasi, inferensi, penjelasan dan pengaturan diri (Facione, 2015).

Mahasiswa yang memiliki kemampuan berpikir kritis cenderung percaya dan bertindak menurut penalarannya secara logis dan sistematis berdasarkan informasi yang diterima (Irwan et al., 2019). Sebagai upaya dalam meningkatkan kemampuan berpikir kritis mahasiswa, perlu adanya desain perangkat pembelajaran yang interaktif dan menarik dengan menggunakan objek sejarah daerah yang diintegrasikan ke dalam mata kuliah. Dengan demikian, mahasiswa akan mampu memahami dan menganalisis sejarah maritim dengan mengintegrasikan sejarah budaya daerah wadu tanda rahi dengan pembelajaran di dalam kelas serta sebagai upaya pelestarian khasanah sejarah budaya daerah.

a. Aktivitas Daring

Pada masa pandemic seperti sekarang belajar secara daring menjadi alternative paling efektif digunakan yaitu menggunakan aplikasi Zoom dan WhatsApp, hanya efektif bagi matakuliah teori dan teori dan praktikum, sedangkan pada matakuliah praktik dan matakuliah lapangan perkuliahan secara online kurang efektif (Hikmat et al., 2020), Pembelajaran Daring bertujuan memberikan layanan pembelajaran bermutu dalam jaringan (daring) yang bersifat masif dan terbuka untuk menjangkau peminat yang lebih banyak dan lebih luas. Daring kombinasi adalah pembelajaran yang mengkombinasikan antara tatap muka dan daring. Daring kombinasi dilaksanakan dengan cara mempersiapkan sistem pembelajaran yang membutuhkan keterlibatan secara langsung antara mahasiswa dan dosen dalam proses pembelajaran. Dalam daring kombinasi pelaksanaan pembelajaran tidak dibatasi ruang dan waktu, yang tidak mewajibkan mahasiswa untuk selalu belajar di dalam ruang kelas dengan segala peraturan yang kaku. (Sofyana \& Rozaq, 2019)
Berdasarkan teori di atas, Pembelajaran daring yang digunakan dalam penelitian ini yaitu Zoom dan Whaatsup, aplikasi ini dipilih dengan beberapa pertimbangan pertimbangan tertentu misalnya efektifitas penyampaian materi, dan kemudahan dalam penggunaan fitur-fitur dalam aplikasi tersebut.

b. Sejarah Maritim

Sejarah maritim menjadi kajian dan wacana yang tidak pernah berhenti di bahas, kaitanya dengan pembelajaran sejarah maritim dalam pandangan Lincoln Paine (2013) mencatat sektor maritim telah mampu menjadi penggerak sejarah umat manusia. Pentingnya kemaritiman dalam kajian sejarah pernah diungkapkan oleh AB Lapian (1992:3) dalam pidato pengukuhannya sebagai guru besar. Ia mengungkapkan bahwa laut adalah pembuka sejarah bangsa Indonesia. Aktivitas kehidupan masyarakat sejak awal penyebarannya terjadi di laut (Utomo, 2014:4), Oleh karena itu, memperkuat budaya maritim tidak dapat dipisahkan dari kajian sejarah maritim yang ada di Indonesia.(Relevansi \& Ahmad, 2017).

Ciri khas bangsa maritim adalah kehebatannya dalam berlayar dan membangun peradaban maritim. Kreativitas dan inovatif melalui ketekunan, melekat karakter dalam perilaku bangsa maritim. Dari rekam jejak, orang-orang yang tinggal di Kepulauan ini telah menunjukkan kemampuannya sebagai bangsa maritim dalam membuka ruang-ruang baru kehidupan yang bersifat global dan mengembangkan budaya maritim.(Zuhdi, 2017), Beradasarkan teori diatas sejarah maritim penting untuk dijelaskan melalui pendidikan, sehingga harus ada mata kuliah sejarah maritim. Dalam penelitian ini materi sejarah maritim akan memuat tentang situs wadu tanda rahi, lopi penge, pelabuhan Bima dan sape, situs Nanga Sia serta bukti sejarah lainya seperti dokumen dan arsip.

c. Situs Budaya Wadu Tanda Rahi, Lopi Penge, Pelabuhan Bima, Pelabuhan Sape, Situs Nanga Sia.

Wadu Tanda Rahi merupakan situs budaya Bima-Dompu yang memiliki nilai sejarah yang tinggi, sebagai symbol budaya Bima-Dompu yang tidak terpisahkan dari laut. Wadu Tanda Rahi berarti Batu yang memandang Suami, situs ini menceritakan kesetiaan seorang istri 
yang menunggu suaminya pulang dari pelayaran panjang.(Alan, 2010).

Lopi Penge, Lopi artinya Perahu dan Penge berarti sebuah kerinduan, merupakan sebuah lagu daerah yang menceritakan tentang kerinduan yang mendalam terhadap seorang kekasih, namun secara makna lagu Lopi Penge tercipta sebagai symbol kebudayaan masyarakat Bima - Dompu yang tidak bisa terpisah dari laut sebagai masyarakat bahari.(Kompas:2014), Pelabuhan Bima dan pelabuhan Sape menjadi salah satu tujuan persinggahan kapal-kapal dagang dari arah Barat dan Timur, berada dalam jalur pelayaran laut Jawa pelabuhan Bima dan sape menjadi pelabuhan dagang yang ramai hingga abad ke-19. (Sumiyati, 2018)

Situs Nanga Sia merupakan peninggalan masa prasejarah, situs Nanga Sia menjadi bukti pemukiman masyarakat Dompu (Hu'u) yang merupakan masyarakat pesisir pantai. Saat penggalian yang dilakukan oleh balai Arkeologi Denpasar dari tahun 2003 sampai tahun 2005 ditemukan sisa gerabah dan dilakukan pengkajian mendalam maka di simpulkan bahwa situs nanga sia merupakan bukti ada masyakat pesisir yang pernah hidup. (Mozaik Budaya Dompu: 2015).

d. Kemampuan berpikir kritis

Berpikir kritis dapat diartikan sebagai upaya seseorang untuk memeriksa kebenaran dari suatu informasi menggunakan keters ediaan bukti, logika, dan kesadaran akan bias (Sulaiman \& Syakarofath, 2018). Menurut Beyer (1995) menawarkan definisi yang paling sederhana: "Berpikir kritis berarti membuat penilaian-penilaian yang masuk akal”.(Zubaidah, 2017). Inti dari kemampuan berpikir kritis yaitu bagian dari cognitive skill yang terdiri dari interprestasi, analisis, evaluasi, inferensi, penjelasan dan pengaturan diri (Facione, 2015).

Berdasarkan teori yang dijelaskan tersebut maka berpikir kritis dalam penelitian ini adalah kemampuan mahasiswa dalam menganalisis sejarah maritim berdasarkan objek sejarah dan budaya daerah Bima yang diaplikasikan dalam model Project based learning, Berdasarkan teori-teori sebelumnya dalam penelitian ini pembelajaran sejarah maritim penting mengintegrasikan sejarah budaya local untuk menjadikan pembelajaran lebih inovatif, kreatif dan lebih bermakna, Berdasarkan Dari urian di atas, dapat disimpulkan bahwa proses pembelajaran yang berlangsung pada prodi Pendikan Sejarah STKIP Yapis Dompu hanya dilakukan melaui penugasan, presentasi dan diskusi kelas. Sehingga perlu dikembangkan sebuah model pembelajaran yang baru dalam hal ini adalah Pengembangan Perangkat pembelajaran berupa RPS, Buku ajar, Worksheet dan soal tes kemampuan berpikir kritis, adapun tujuan dari penelitian ini yaitu menghasilkan perangkat pembelajaran Daring Sejarah Maritim Wadu Tanda Rahi menggunakan model Project Based Learning (PjBL) untuk meningkatkan kemampuan berpikir kritis mahasiswa.

\section{METODE PENELITIAN}

Penelitian ini merupakan penelitian dan pengembangan (Research and Development (R\&D) yang bertujuan untuk mengembangkan Perangkat Pembelajaran berupa: RPS, LKM, buku ajar ber-ISBN dan soal tes kemampuan berpikir kritis, Model yang digunakan sebagai dasar untuk mengembangkan Perangkat Pembelajaran ini yaitu model 4-D (four-D) model, Penenlitian ini dilaksanakan pada mahasiswa Program Studi Pendidikan Sejarah semester V dengan jumlah mahasiswa sebanyak 20 orang, tahun pelajaran 2020/2021, Pengembangan Perangkat Pembelajaran Sejarah Maritim "Wadu Ntanda Rahi" Berbasis Project Based Learning (PjBL) dilakukan menggunakan modifikasi Four-D Models (Model 4-D) yang terdiri dari 4 tahap yaitu: Define, Design, Develop, dan Desimination, Teknik analisis data yang dilakukan dalam penelitian ini terdiri atas: 1) analisis data hasil Validasi, yang merupakan analisis berdasarkan masukan, komentar, dan saran dari validator sebagai pedoman dalam merevisi perangkat pembelajaran. Perangkat pembelajaran dikatan valid jika berada pada katagori rata-rata $>2,50$. Dengan demikian, hasil analisis data yang tidak memenuhi salah satu kategori baik atau sangat baik akan dijadikan bahan pertimbangan untuk dilakukan revisi, 2) analisis data hasil ujicoba yang terdiri atas a) Analisis data kemampuan dosen mengelola pembelajaran, b) Analisis data aktivitas mahasiswa, c) analisis data respon mahasiswa terhadap pembelajaran, dan analisis data tes hasil belajar mahasiswa.

\section{HASIL DAN PEMBAHASAN}

Hasil penelitian ini disusun berdasarkan perolehan data hasil validasi serta ujicoba perangkat pembelajaran yang dilaksanakan di STKIP Yapis Dompu Tahun 2021 dijelaskan 
sebagai berikut:

a) Analisis Data Hasil Validasi

Kegiatan pertama yang dilakukan pada tahap pengembangan adalah meminta masukan para ahli pendidikan sejarah (validator). Masukan yang diberikan berupa penilaian dan saran-saran perbaikan perangkat. Hasil dari validasi digunakan sebagai dasar untuk mengambil keputusan tentang kelayakan dan merevisi perangkat pembelajaran. Draft perangkat pembelajaran hasil revisi berdasarkan masukan para ahli disebut draft I(i). Perangkat pembelajaran yang dinyatakan valid oleh validator dinamakan draft II.

1. Hasil Validasi Rencana Pelaksanaan Pembelajaran (RPS)

Hasil validasi rencana pelaksanaan pembelajaran yang diberikan kepada validator berisi tentang penilaian dan komentar saran-saran perbaikan, hasil validasi menunuukan bahwa rata-rata penilaian setiap indikatir untuk semua aspek berada dalam katagori baik dan sangat baik, sehingga dapat dinyatakan bahwa RPS dalam draf 1 bernilai valid. Secara umum, validator menyatakan RPS berniali sangat baik dan dapat digunakan dengan revisi kecil, Revisi dilakukan berdasarkan saran-saran validator, seperti alokasi waktu yang diberikan untuk setiap kegiatan pembelajaran

2. Hasil Validasi Lembar Kegiatan Mahasiswa (LKM)

Instrumen validasi yang diberikan kepada validator berisi tentang penilaian dan komentar saran-saran perbaikan. Revisi yang dilakukan sesuai dengan saransaran validator, seperti perbaikan penggunaan bahasa serta pemuktahiran referensi. dari hasil validasi menunjukkan bahwa rata-rata setiap indikator pada semua aspek yang dinilai berada pada kategori baik dan sangat baik. Hasil penilaian secara umum terhadap LKS menunjukkan bahwa LKS berkualitas sangat baik. Sehingga dapat digunakan dengan sedikit revisi.

3. Hasil Validasi instrument Tes

Instrument tes kemampuan berpikir kritis mahasiswa setelah divalidasi menunjukan bahwa, rata-rata setiap indicator pada semua aspek yang dinilai berada pada katagori baik dan sangat baik. Hasil penilaian secara umum terhadap indikatir tes kemampuan berpikir kritis mahasiswa berkualitas sangat baik sehingga dapat digunakan dengan sedikit revisi, Revisi dilakukan sesuai dengan saran-saran dari validator, seperti penggunaan kalimat yang kurang tepat

4. Hasil validasi angket Respon mahasiswa

Instrumen validasi angket respon mahasiswa yang diberikan kepada validator, berisi tentang penilaian dan komentar saran-saran perbaikan, Hasil validasi angket respon mahasiswa menunjukan bahwa rata-rata setiap indikator pada semua aspek yang dinilai berada pada kategori baik dan sangat baik. Hasil penilaian secara umum terhadap angket respon mahasiswa menunjukkan bahwa angket respon mahasiswa berkualitas sangat baik sehingga dapat digunakan dengan revisi kecil, Revisi dilakukan sesuai dengan saran-saran dari validator, seperti penggunaan istilah dan perbaikan bahasa kalimat.

b) Analisis Data hasil Ujicoba

Uji coba lapangan dilakukan untuk memperoleh data atau masukan dari guru, mahasiswa, dan para pengamat (observer) terhadap semua perangkat pembelajaran yang telah disusun sebagai dasar untuk melakukan revisi (penyempurnaan) draft III menjadi draft final. Pengambilan kelas uji coba dilakukan dengan teknik random sampling. Teknik ini digunakan untuk memilih satu kelas dari empat kelas yang memiliki kemampuan yang sama. Melalui teknik random sampling kelas yang terpilih sebagai kelas uji coba adalah kelas A. Pelaksanaan uji coba melibatkan satu orang Dosen Mitra yang bertugas sebagai pelaksana penerapan perangkat pembelajaran draf III dan dua orang pengamat yang bertugas mengamati aktvitas mahasiswa dan bertugas mengamati keterlaksanaan perangat pembelajaran.

Data yang diperoleh dari uji coba lapangan dianalisis dengan teknik analisis data yang telah diuaraikan pada Bab III. Hasil analisis dijadikan sebagai bahan pertimbangan untuk merevisi draft III menjadi draft final. Data yang diambil dari uji coba lapangan meliputi data kemampuan guru mengelola pembelajaran, data aktivitas Mahasiwa, data respon Mahasiwa, data tes awal, dan data tes akhir. Data kemampuan guru mengelola pembelajaran dikumpulkan menggunakan instrumen lembar pengamatan pengelolaan 
pembelajaran. Data aktivitas Mahasiwa dikumpulkan dengan menggunakan instrumen lembar pengamatan aktivitas Mahasiwa. Data respon Mahasiwa dikumpulkan menggunakan angket respon Mahasiwa. Sedangkan data tes awal dan tes akhir dikumpulkan dengan Tes kemampuan berpikir kritis.

1. Analisis data kemampuan dosen mengelola pembelajaran

Berdasarkan katagori kemampuan dosen dalam mengelola pembelajaran mengidentifikasikan bahwa pembelajaran berjalan dengan efektif. Hasil ini diperoleh karena rata-rata skor setiap aspek kemampuan dosen mengelola pembelajaran dinilai pada setiap RPS mencapai katagori minimal baik.

Tabel 1. Hasil penilaian kemampuan guru mengelola pembelajaran

\begin{tabular}{|c|c|c|c|c|c|}
\hline \multirow[b]{2}{*}{ No } & \multirow[b]{2}{*}{ Aspek yang diamati } & \multicolumn{4}{|c|}{ Penilaian } \\
\hline & & $\begin{array}{c}\text { Skor } \\
\text { RPP } \\
1\end{array}$ & $\begin{array}{c}\text { Skor } \\
\text { RPP } \\
2\end{array}$ & $\begin{array}{c}\text { Skor } \\
\text { RPP } \\
3\end{array}$ & $\begin{array}{c}\text { Skor } \\
\text { RPP } \\
4\end{array}$ \\
\hline I & $\begin{array}{l}\text { Kemampuan Melakukan } \\
\text { Orientasi Pembelajaran: }\end{array}$ & & & & \\
\hline 1. & Memotivasi/ & 3 & 3 & 4 & 4 \\
\hline 2. & $\begin{array}{l}\text { membangkitkan minat } \\
\text { mahasiswa. }\end{array}$ & 4 & 3 & 3 & 4 \\
\hline 3. & $\begin{array}{l}\text { Menginformasikan } \\
\text { tujuan pembelajaran. } \\
\text { Dan Memberikan } \\
\text { apersepsi/ materi } \\
\text { prasyarat. }\end{array}$ & 3 & 3 & 4 & 4 \\
\hline II & $\begin{array}{l}\text { Kemampuan } \\
\text { Memberikan } \\
\text { Pembekalan: }\end{array}$ & & & & \\
\hline 1. & $\begin{array}{l}\text { Menyajikan contoh soal } \\
\text { terbuka, dan }\end{array}$ & 4 & 3 & 3 & 3 \\
\hline 2. & $\begin{array}{l}\text { Memberikan contoh cara } \\
\text { menjawab soal terbuka. }\end{array}$ & 4 & 3 & 3 & 3 \\
\hline III & $\begin{array}{l}\text { Kemampuan Mengelola } \\
\text { mahasiswa Saat } \\
\text { Pengerjaan LKS Secara } \\
\text { Individu: }\end{array}$ & & & & \\
\hline 1. & $\begin{array}{l}\text { Membimbing mahasiswa } \\
\text { memahami soal. }\end{array}$ & 3 & 4 & 4 & 4 \\
\hline 2. & $\begin{array}{l}\text { Menjelaskan maksud } \\
\text { soal kepada mahasiswa } \\
\text { yang belum paham. }\end{array}$ & 3 & 4 & 4 & 4 \\
\hline 3. & $\begin{array}{l}\text { Berkeliling mengelola } \\
\text { mahasiswa. }\end{array}$ & 3 & 3 & 4 & 4 \\
\hline IV & $\begin{array}{l}\text { Kemampuan Mengelola } \\
\text { Diskusi Kelompok }\end{array}$ & & & & \\
\hline 1. & $\begin{array}{l}\text { Mendorong mahasiswa } \\
\text { untuk berdiskusi. }\end{array}$ & 3 & 3 & 4 & 4 \\
\hline 2. & $\begin{array}{l}\text { Mendorong mahasiswa } \\
\text { untuk membandingkan } \\
\text { jawaban. }\end{array}$ & 3 & 4 & 3 & 4 \\
\hline 3. & $\begin{array}{l}\text { Membantu/ } \\
\text { mengarahkan kelompok } \\
\text { yang mengalami } \\
\text { kesulitan. }\end{array}$ & 4 & 4 & 4 & 4 \\
\hline 4. & $\begin{array}{l}\text { Berkeliling mengelola } \\
\text { mahasiswa. }\end{array}$ & 4 & 4 & 4 & 4 \\
\hline $\mathrm{V}$ & $\begin{array}{l}\text { Kemampuan Mengelola } \\
\text { Presentasi }\end{array}$ & & & & \\
\hline
\end{tabular}

\begin{tabular}{|c|c|c|c|c|c|}
\hline 1. & $\begin{array}{l}\text { Meminta kelompok } \\
\text { mempresentasikan } \\
\text { jawabannya. }\end{array}$ & 4 & 3 & 3 & 3 \\
\hline 2. & $\begin{array}{l}\text { Mendorong kelompok } \\
\text { lain untuk bertanya atau } \\
\text { menanggapi. }\end{array}$ & 3 & 3 & 3 & 4 \\
\hline 3. & Melengkapi jawaban. & 3 & 2 & 3 & 4 \\
\hline 4. & $\begin{array}{l}\text { Mengelola diskusi saat } \\
\text { presentasi. }\end{array}$ & 3 & 3 & 3 & 4 \\
\hline VI & $\begin{array}{l}\text { Kemampuan Mengelola } \\
\text { Penarikan Kesimpulan } \\
\text { Membimbing mahasiswa } \\
\text { menyimpulkan jawaban } \\
\text { LKS. }\end{array}$ & 3 & 3 & 3 & 3 \\
\hline VII & $\begin{array}{l}\text { Kemampuan } \\
\text { Pengelolaan Waktu }\end{array}$ & 3 & 3 & 3 & 3 \\
\hline VIII & $\begin{array}{l}\text { Kemampuan } \\
\text { Memberikan }\end{array}$ & & & & \\
\hline 1. & $\begin{array}{l}\text { Pertanyaan/ Penguatan. } \\
\text { Memberikan } \\
\text { pertanyaan/ penguatan }\end{array}$ & 3 & 4 & 4 & 4 \\
\hline 2. & $\begin{array}{l}\text { yang bersifat arahan } \\
\text { untuk membantu } \\
\text { mahasiswa dalam }\end{array}$ & 3 & 3 & 4 & 4 \\
\hline 3. & $\begin{array}{l}\text { mengerjakan LKS secara } \\
\text { individu. } \\
\text { Memberikan } \\
\text { pertanyaan/penguatan } \\
\text { yang bersifat arahan } \\
\text { untuk membantu } \\
\text { mahamahamahasiswa } \\
\text { dalam diskusi kelompok. } \\
\text { Memberikan } \\
\text { pertanyaan/penguatan } \\
\text { pada } \\
\text { saat presentasi. }\end{array}$ & 3 & 4 & 4 & 4 \\
\hline
\end{tabular}

2. Analisis data aktivitas mahasiswa Jumlah mahasiswa yang diamati 4 orang, yaitu 1 orang dari kelompok atas, 2 orang dari kelompok tengah, dan 1 orang dari kelompok bawah. Pengamatan dilakukan oleh satu orang. berdasarkan kriteria keefektifan aktivitas mahasiswa yang telah diuraikan menunjukkan bahwa uji coba ini dikategorikan efektif. Hal ini dikarenakan hasil pengamatan menunjukkan bahwa setiap aspek aktivitas mahasiswa untuk semua rencana pelaksanaan pembelajaran (RPS) berada pada interval kriteria batas toleransi waktu ideal.

3. Analisis data respon mahasiswa terhadap pembelajaran

Angket respon mahasiswa dibagikan kepada mahasiswa setelah pembelajaran sejarah maritime dengan metode project Based learning selesai, adapun rekapitulasi hasil angket respon mahasiswa dapat dilihat pada Tabel berikut:

Tabel 2. Hasil Angket Respon mahasiswa

\begin{tabular}{clcccc}
\hline No & Aspek yang direspon & SS & S & TS & STS \\
\hline 1. & $\begin{array}{l}\text { Membuat pernyataan dengan } \\
\text { bahasa sendiri berdasarkan } \\
\text { gambar atau informasi yang } \\
\text { disediakan menyenangkan }\end{array}$ & 16 & 7 & & \\
\hline
\end{tabular}




\begin{tabular}{|c|c|c|c|c|c|}
\hline & $\begin{array}{l}\text { karena saya dapat berkreasi } \\
\text { sesuai dengan ide saya sendiri. }\end{array}$ & & & & \\
\hline 2. & $\begin{array}{l}\text { Berpartisipasi aktif dalam } \\
\text { pembelajaran membuat saya } \\
\text { bingung dalam mempelajari } \\
\text { logika. }\end{array}$ & & & 15 & 8 \\
\hline 3. & $\begin{array}{l}\text { Membuat beberapa pernyataan } \\
\text { sesuai dengan gambar atau } \\
\text { informasi yang disediakan } \\
\text { merupakan sesuatu yang menarik } \\
\text { dan merupakan cara mengajar } \\
\text { yang baru. }\end{array}$ & 9 & 14 & & \\
\hline 4. & $\begin{array}{l}\text { Dalam mengikuti pembelajaran } \\
\text { ini tidak harus menguasai materi } \\
\text { sebelumnya. }\end{array}$ & & 5 & 10 & 8 \\
\hline 5. & $\begin{array}{l}\text { Saat mengikuti pembelajaran ini, } \\
\text { saya yakin dapat memperkaya } \\
\text { pengalaman dalam } \\
\text { menyelesaikan masalah, karena } \\
\text { diharuskan untuk menjawab atau } \\
\text { menyelesaikan masalah dengan } \\
\text { banyak cara/jawaban yang benar. }\end{array}$ & 10 & 13 & & \\
\hline 6. & $\begin{array}{l}\text { Membuat pernyataan dengan } \\
\text { bahasa sendiri berdasarkan } \\
\text { gambar atau informasi yang } \\
\text { disediakan tidak menyenangkan. }\end{array}$ & & 1 & 11 & 11 \\
\hline 7. & $\begin{array}{l}\text { Berpartisipasi aktif dalam } \\
\text { pembelajaran membuat saya } \\
\text { mudah mengingat tentang materi } \\
\text { logika dan memperkaya ide } \\
\text { matematik saya. }\end{array}$ & 11 & 12 & & \\
\hline 8. & $\begin{array}{l}\text { Masalah yang disajikan tidak } \\
\text { menarik. }\end{array}$ & & 1 & 18 & 4 \\
\hline 9. & $\begin{array}{l}\text { Mengikuti pembelajaran ini } \\
\text { mengharuskan saya menguasai } \\
\text { materi sebelumnya. }\end{array}$ & 1 & 17 & 5 & \\
\hline 10. & $\begin{array}{l}\text { Mengikuti pembelajaran tidak } \\
\text { mengembangkan kemampuan } \\
\text { bernalar saya. }\end{array}$ & & & 12 & 11 \\
\hline 11. & $\begin{array}{l}\text { Masalah yang disajikan menarik, } \\
\text { sehingga mengharuskan saya } \\
\text { merespon masalah dari berbagai } \\
\text { sudut pandang }\end{array}$ & 7 & 16 & & \\
\hline 12. & $\begin{array}{l}\text { Pada saat diskusi, membuat saya } \\
\text { banyak belajar tentang } \\
\text { menghargai pendapat orang lain } \\
\text { dan bertanggung jawab kepada } \\
\text { diri sendiri maupun kelompok, } \\
\text { serta meningkatkan kemampuan } \\
\text { mengkomunikasikan ide. }\end{array}$ & 8 & 15 & & \\
\hline 13. & $\begin{array}{l}\text { Mengikuti pembelajaran } \\
\text { mendorong saya untuk } \\
\text { mengembangkan kemampuan } \\
\text { bernalar. }\end{array}$ & 9 & 13 & 1 & \\
\hline 14. & $\begin{array}{l}\text { Mengikuti pembelajaran ini sama } \\
\text { sekali tidak memperkaya } \\
\text { pengalaman dalam } \\
\text { menyelesaikan masalah. }\end{array}$ & & & 16 & 7 \\
\hline
\end{tabular}

Berdasarkan kriteria bahwa Respon mahasiswa dikategorikan positif jika mahasiswa memilih aspek positif atau aspek negatif yang tertera pada angket dengan persentase $\geq 70 \%$. untuk aspek yang persentasenya kurang dari $70 \%$ maka akan digunakan sebagai dasar untuk merevisi perangkat pembelajaran. Dari tabel diatas menunjukan menunjukkan bahwa respon mahasiswa terhadap pembelajaran menunjukan $70 \%$ mahasiswa memberikan respon dengan kategori positif.

4. Analisis data tes hasil belajar mahasiswa Tujuan dari diantaranya untuk memperoleh data tentang validitas butir tes, reliabilitas tes, dan sensitivitas butir tes, ketiga indikator ini merupakan penentu keputusan apakah tes yang dikembangkan perlu direvisi atau tidak. Hasil analisis validitas butir tes, reliabilitas tes, dan sensitifitas butir tes sebagai berikut:

a. Validitas

Berdasarkan rumus korelasi product moment diperoleh validitas setiap butir tes berada pada kategori cukup dan tinggi. Dengan demikian semua butir soal Tes kemampuan berpikir kritis valid.

b. Reliabilitas

Reliabilitas tes menunjukkan koefisien reliabilitas sebesar 0,87. Angka ini menunjukkan bahwa reliabilitas instrumen Tes kemampuan berpikir kritis termasuk dalam kategori "tinggi". Dengan demikian, instrumen Tes kemampuan berpikir kritis dapat dikatakan reliabel.

c. Sensitivitas

Sensitivitas setiap butir tes menunjukkan bahwa setiap butir tes sensitif terhadap pembelajaran. Berdasarkan hasil analisis validitas butir tes, reliabilitas tes, dan sensitivitas butir tes. Maka, THB dapat dikategorikan baik.

d. Uji Keterbacaan

Perangkat pembelajaran yang telah diperoleh berdasarkan hasil validasi dinamakan draft II. Sebelum draft II diimplementasikan atau diujicobakan di lapangan terlebih dahulu dilakukan uji keterbacaan. Uji keterbacaan dilakukan dengan cara memberikan draft II (meliputi LKS dan Lembar Tes kemampuan berpikir kritis) kepada 3 orang mahasiswa semester 5 STKIP Yapis Dompu yang memiliki kemampuan akademik tinggi, sedang, dan rendah, Hasil uji keterbacaan menunjukkan bahwa LKS dan Tes Kemampuan berpikir kritis perlu diperbaiki. Perbaikan tersebut dilakukan agar LKS dan Tes kemampuan berpikir kritis lebih mudah dipahami oleh mahasiswa, Hasil revisi 
draft II yang telah dinyatakan valid dinamakan draft III yang akan digunakan untuk uji coba.

\section{SIMPULAN}

Beberapa hal yang dapat dicatat dalam penelitian ini berdasarkan temuan pada saat validasi ahli dan uji coba lapangan, diuraikan atas: Hasil penelitian ahli/ validator menunjukan bahwa, perangkat pembelajaran yang terdiri dari RPS, LKS, dan tes kemampuan berpikir kritis mahasiswa ditinjau dari indicator format, bahasa, isi dikatagorikan baik. Hal ini ditunjukan dengan rata-rata skor penilaian ahli terhadap RPS. LKS dan lembar tes kemampuan berpikir kritis mahasiswa lebih dari 3,50. Secara umum, perangkat pembelajaran sejarah maritime wadu tanda rahi dengan metode PjBL di Prodi pendidikan sejarah STKIP Yapis Dompu yang dikembangkan berada pada katagori "sangat baik" dan dapat digunakan dengan sedikit revisi. Jadi secara keseluruhan perangkat pembelajaran sejarah maritime wadu tanda rahi dengan metode PjBL baik menurut para ahli, sedangkan untuk Respon mahasiswa terhadap pembelajaran, hasil analisis data respon mahasiswa terhadap komponen dan kegiatan pembelajaran sejarah maritime wadu tanda rahi dengan metode PjBL menunjukkan lebih dari 70\% mahasiswa memberikan respon dengan kategori "positif" untuk tiap-tiap aspek, selain itu Hasil analisis validitas butir tes, reliabilitas tes, dan sensitivitas butir tes menunjukkan bahwa semua butir tes hasil belajar topik logika memiliki validitas cukup dan tinggi, hal ini sejalan dengan yang dikemukakan Arikunto bahwa suatu butir dinyatakan valid jika koefisien validitas butir tersebut diinterpretasikan minimal cukup. Reliabilitas tes hasil belajar termasuk dalam kategori tinggi, dan semua butir tes sensitif terhadap pembelajaran. hal ini juga sejalan dengan yang dikemukakan Ratumanan dan Laurens bahwa suatu tes ddinyatakan reliabel jika koefisien reliabilitas tes tersebut diinterpretasikan minimal cukup dan suatu butir tes dikatakan sensitif apabila indeks sensitivitasnya berada antara 0,00 dan 1,00. Sehingga Tes kemampuan berpikir kritis dikategorikan "baik".

Berdasarkan pembahasan di atas dan apa yang telah diuraikan perangkat pembelajaran ini dapat disimpulkan memenuhi kategori baik. Sebab keenam syarat terpenuhi: (a) valid berdasarkan penilaian ahli, (b) kemampuan dosen dalam mengelola pembelajaran efektif, (c) aktifitas mahasiswa efektif, (d) respon mahasiswa positif terhadap pembelajaran, dan (e) tes kemampuan berpikir kritis mahasiswa valid, reliable, dan sensitive. Oleh karena itu, perangkat pembela-jaran sejarah maritime Wadu tanda rahi dengan model PjBL memenuhi kategori "baik".

\section{DAFTAR RUJUKAN}

Andy Purnomo, E., \& Rohman, A. (2015). Efektivitas Penerapan Model Pembelajaran Project Based Learning (Pbl) Berbasis Maple Matakuliah Kalkulus Lanjut Ii. Jkpm, 2(2), 20-24.

Facione, P. A. (2015). Critical Thinking: What It Is and Why It Counts. 1-30.

Hikmat, Hermawan, E., Aldim, \& Irwandi. (2020). Efektivitas Pembalajaran Daring Selama Masa Pandemi Covid-19: Sebuah Survey Online. Digital Library, UIN SUnan Gung Djati, Bandung.

Irwan, I., Maridi, M., \& Dwiastuti, S. (2019). Developing guided inquiry-based ecosystem module to improve students' critical thinking skills. Jurnal Pendidikan Biologi Indonesia, 5(1), 51-60. https://doi.org/10.22219/jpbi.v5i1.7287

Nurfitriyanti, M. (2016). Model Pembelajaran Project Based Learning Terhadap Kemampuan Pemecahan Masalah Matematika. Formatif: Jurnal Ilmiah Pendidikan MIPA, 6(2), 149-

Rajabi, M., Ekohariadi, E., \& Buditjahjanto, I. (2015). Pengembangan Perangkat Pembelajaran Instalasi Sistem Operasi Dengan Model Pembelajaran Berbasis Proyek. Jurnal Pendidikan Vokasi UNESA, 3(01), 247005.

Relevansi, U. D. A. N., \& Ahmad, T. A. (2017). Urgensi Dan Relevansi Pembelajaran Sejarah Maritim Untuk Wilayah Pedalaman. Paramita - Historical Studies Journal, 27(1), 113-126.

https://doi.org/10.15294/paramita.v27i1.9 190

Sadikin, A., \& Hamidah, A. (2020). Pembelajaran Daring di Tengah Wabah Covid-19. BIODIK. https://doi.org/10.22437/bio.v6i2.9759

Sofyana, L., \& Rozaq, A. (2019). Pembelajaran 
Daring Kombinasi Berbasis Whatsapp Pada Kelas Karyawan Prodi Teknik Informatika Universitas Pgri Madiun. Jurnal Nasional Pendidikan Teknik Informatika (JANAPATI), 8(1), https://doi.org/10.23887/janapati.v8i1.172 04

Sulaiman, A., \& Syakarofath, N. A. (2018). Berpikir Kritis: Mendorong Introduksi dan Reformulasi Konsep dalam Psikologi Islam. Buletin Psikologi, 26(2), 86. https://doi.org/10.22146/buletinpsikologi. 38660

Sumiyati, S. (2018). Eksistensi Bima Dalam Pelayaran Dan Perdagangan Antar Pulau. Diakronika, 18(1), 39. https://doi.org/10.24036/diakronika/vol1 8-iss1/60
Yuliati. (2014). Kejayaan Indonesia Sebagai Negara Maritim. Jurnal Pendidikan Pancasila Dan Kewarganegaraan, 27(2), 6. https://doi.org/http://dx.doi.org/10.17977 /jppkn.v27i2.5523

Zubaidah, S. (2017). Berfikir Kritis :kemampuan Berpikir Tingkat Tinggi Yang dapat Dikembangkan Melalui Pembelajaran Sains, Jurusan Biologi FMIPA Universitas Negeri Malang. January 2010, 100.

Zuhdi, S. (2017). The Character of Maritime Nation In Facing The Global Challenge: A Historical Perspective. Historia: Jurnal Pendidik Dan Peneliti Sejarah, 13(2), 217. https://doi.org/10.17509/historia.v13i2.6 $\underline{213}$ 